\title{
THE EFFECT OF LOCAL COOLING ON THE FILTRATION AND ABSORPTION OF FLUID IN THE HUMAN FOREARM
}

\author{
By ELLEN BROWN,1 CHARLES S. WISE,2 AND EDWIN O. WHEELER \& \\ (From the Department of Physiology, Harvard Medical School, Boston, Mass)
}

(Received for publication April 10, 1947)

Studies relating to the effects of cold on the permeability of human capillaries to protein and fluid have assumed practical importance in recent years because of current interest in refrigeration anesthesia and cryotherapy, as well as because of the casualties caused by exposure to cold during the recent war. Clinical (1) and experimental $(2,3)$ studies have shown that true frostbite increases the permeability of the capillary wall to both protein and fluid, but less is known quantitatively concerning the immediate effects of temperatures not sufficiently low to freeze the tissues but still injurious enough to produce serious lesions such as "immersion foot" (4).

Lewis showed (5) that immersing the hands in water at various temperatures produced least change in their volume in the range from $15^{\circ}$ to $20^{\circ} \mathrm{C}$. At $10^{\circ} \mathrm{C}$. or less, and at $25^{\circ} \mathrm{C}$. or more, their volume increased. After prolonged immersion at $5^{\circ} \mathrm{C}$., aspirated edema fluid contained approximately 3 per cent protein. These results suggested strongly that capillary permeability was increased by moderate cold but were not conclusive because the observed changes occurred while venous pressure was elevated and because changes in vascular volume could not be entirely excluded. At about the same time Lange (6) came to the opposite conclusion, viz. that the permeability of cutaneous capillaries in man and the rabbit is decreased by cold because the appearance in the skin of intravenously injected fluorescein was delayed at a temperature of $10^{\circ} \mathrm{C}$. However, the rapid diffusibility of this dye makes it a very uncertain indicator of capillary permeability; it seems more likely that reduced blood flow, not decreased permeability, was responsible for the observed delay in staining of the skin.

\footnotetext{
1 Research Fellow in Physiology, Commonwealth Fund.

2 Research Fellow in Physiology, Baruch Committee on Physical Medicine.

${ }^{8}$ Graduate Assistant in Medicine, Massachusetts General Hospital.
}

To obtain more quantitative information, the pressure plethysmograph of Landis and Gibbon (7) was used to measure changes in the volume of extravascular fluid in the forearm during exposure to external temperatures ranging from $44.5^{\circ}$ to $4.5^{\circ} \mathrm{C}$. It was found that moderate cooling $(a)$ increased the extravascular volume of the forearm even when venous pressure was normal, (b) decreased the rate of filtration produced by a given increase of venous pressure and $(c)$ decreased the rate at which extravascular fluid was reabsorbed. The evidence is consistent with the view that the human capillary wall becomes increasingly permeable to protein and fluid as environmental temperature falls below $25^{\circ} \mathrm{C}$., but it also appears that other factors influence the rate at which edema develops during exposure to cold.

\section{METHODS}

The pressure plethysmograph of Landis and Gibbon $(7,8)$ was used throughout. The particular advantage of this method is that the volume of a segment of forearm can be measured very precisely while it is exposed intermittently for brief periods to an external pressure of 200 $\mathrm{mm}$. Hg. This pressure is sufficient to collapse the blood vessels and thus to exclude almost completely the large and unpredictable changes in volume which are caused by vasodilatation or vasoconstriction. By excluding such changes in vascular volume, the accumulation of relatively minute amounts of extravascular fluid could be measured with little error. The effects of temperature could also be studied because the plethysmograph had double walls between which water at any desired temperature could be circulated. The apparatus and general methods used in this study were essentially the same as those described by Landis and Gibbon (7) to whose paper the reader is referred for a detailed description and diagrams.

One important modification in procedure was introduced. Landis and Gibbon (7) began their observations after the subjects had reclined for 30 minutes with the forearm in the plethysmograph. In the observations now described the subjects reclined with the forearm supported in a vertical position for a total of 90 minutes, during the last $\mathbf{3 0}$ minutes of which the plethysmograph was being adjusted and filled. This was done in order to insure complete $a \dot{b}-$ sorption (by the capillaries) or drainage (by the lym- 
phatics) of any. extravascular fluid that might have accumulated as a result of previous activity or dependency of the forearm. This prolonged preparation increased the accuracy of the method and also led to modification of certain conclusions reached by Landis and Gibbon (7).

Temperatures were measured at intervals of 5 minutes or less by appropriately placed thermal junctions, viz. in the water surrounding the arm in the plethysmograph, on the skin of the forearm within the plethysmograph, on the skin of the wrist just outside the plethysmograph, and in room air near the plethysmograph. Water from a cool or warm reservoir was circulated at a rate of 5 liters per minute through the space between the inner and outer walls of the plethysmograph and through a jacket surrounding an accessory vessel between the plethysmograph and the burette (7). This kept the water surrounding the arm in the plethysmograph at the desired levels within $1^{\circ} \mathrm{C}$. except for transient deviations of not more than $1.5^{\circ} \mathrm{C}$., about the average which occurred occasionally as water moved rapidly into or out of the plethysmograph during determinations of volume. For the sake of brevity, only average temperature, i.e., $4.5^{\circ}$ for $4^{\circ}$ to $5^{\circ}$ or $14.5^{\circ}$ for $14^{\circ}$ to $15^{\circ}$, etc., will be given in the text, it being understood that the range was about plus or minus $0.5^{\circ} \mathrm{C}$. as indicated in the charts and tables.

The midpoint of the plethysmograph, with the forearm vertical, was placed level with the manubrium sterni. A pneumatic cuff, $15 \mathrm{~cm}$. in width, was wrapped around the upper arm. Before beginning observations, this was inflated to determine the lowest cuff pressure which would cause an increase in total arm volume. This precaution was taken to avoid possible errors which might arise if the diaphragms of the plethysmograph were applied so snugly that they themselves produced venous congestion. The same cuff was used in certain experiments to produce venous congestion. For this purpose, pressure in the cuff was raised to the desired level plus the additional correction required because of the position of the forearm and the water surrounding it in the plethysmograph (7).

Each determination of "reduced" or "avascular" forearm volume involved application of a pressure of $200 \mathrm{~mm}$. $\mathrm{Hg}$ to the water in the plethysmograph for a period of 2 minutes, during which burette readings were made every 30 seconds. Only the last of each set of readings was used to calculate the change in reduced forearm volume that had occurred since the preceding determination. Pressure was usually applied for 2 minutes out of every 10, 8 minutes being allowed for recovery. When venous congestion was imposed between successive determinations, the interval was increased so that the actual time during which filtration occurred and the forearm was not exposed to external pressure was 10 minutes. In certain control observations for special purposes, pressure was applied for 2 minutes out of every 5,20 , or 60 minutes.

At the conclusion of each experiment the upper and lower circumferences of the segment of forearm within the plethysmograph were measured and the approximate volume of the segment was calculated.

Four normal individuals, 3 male and 1 female, aged between 20 and 33, served as subjects throughout. A few supplementary observations were made on another female subject.

\section{OBSERVATIONS}

\section{Control studies of "reduced forearm volume" at $34.5^{\circ} \mathrm{C}$.}

Landis and Gibbon (7) observed a significant decline in reduced forearm volume during control observations at this and other temperatures. By making few or many determinations over a period of 1 hour or more they concluded that this decline in volume was due chiefly to a real absorption of fluid and only slightly to the mechanical effects of the repeatedly applied external pressure. They omitted, however, the preliminary "emptying" of the forearm which in the present observations reduced the volume of extravascular fluid to a minimum prior to each experiment. When this precaution was taken the existence of a systematic mechanical artefact became clear.

In 2 experiments on each of the 4 regular subjects, reduced forearm volume was measured repeatedly at intervals of 10 minutes for 60 to 80 minutes while the water in the plethysmograph was kept at a neutral temperature, viz. $34.5^{\circ} \mathrm{C}$. As shown in Figure 1 (solid dots and solid line) re-

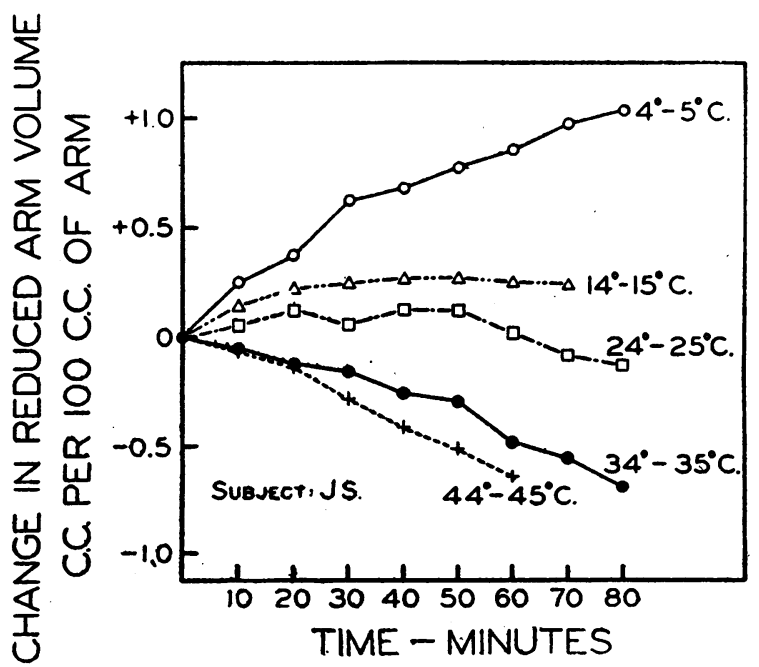

Fig. 1. Changes in Reduced Forearm Volume, in ML. PER 100 ML. OF Forearm, Under Resting Conditions at Plethysmograph Temperatures of $4-5^{\circ}, 14-15^{\circ}$, 24-25. $34-35^{\circ}$, AND $44-45^{\circ} \mathrm{C}$.

A pressure of $200 \mathrm{~mm}$. $\mathrm{Hg}$ was applied to the contents of the plethysmograph for 2 minutes out of every 10 for determination of reduced forearm volume. Subject J. $\mathrm{S}$. 
duced forearm volume decreased steadily; this was true of all 8 experiments. In 62 measurements of reduced forearm volume the average change per 10 -minute period was $-.08 \mathrm{ml}$. per $100 \mathrm{ml}$. of forearm tissue (range from +.11 to $-.33 \mathrm{ml}$. per $100 \mathrm{ml}$. of tissue; standard deviation .073). For the 3 male subjects the average change of reduced forearm volume per 10-minute period was between -.06 and $-.08 \mathrm{ml}$. per $100 \mathrm{ml}$.; for the female subject, $-.13 \mathrm{ml}$. per $100 \mathrm{ml}$. In 2 similar experiments using a second female subject the average change per 10 -minute period was $-.16 \mathrm{ml}$. per $100 \mathrm{ml}$.

To determine whether this slight but definite decrease in volume was due to true absorption of extravascular fluid or was simply a pressure artefact, serial determinations were made for a period of 1 hour at intervals of 5,10 , and 20 minutes. It was found that the rate of decrease in control volume was related to the number of readings (and number of periods of external pressure) and not to total elapsed time. Thus, over a period of 60 minutes, 12 determinations decreased the volume by an average total of $-.79 \mathrm{ml}$. per $100 \mathrm{ml}$. of forearm, 6 determinations decreased it by $-.55 \mathrm{ml}$. per $100 \mathrm{ml}$, and 3 determinations by $-.28 \mathrm{ml}$. per $100 \mathrm{ml}$. The mean decrease of reduced forearm volume per determination at 5-minute intervals was $-.06 \mathrm{ml}$. per $100 \mathrm{ml}$., and, at 20 -minute intervals, $-.10 \mathrm{ml}$. per $100 \mathrm{ml}$. Both were within the limits of the probable error of the mean $(-.03$ to -.13 ) observed when determinations were made every 10 minutes.

In a single experiment, one pair of determinations 10 minutes apart was separated by a 60 minute interval from another pair of readings 10 minutes apart. Reduced forearm volume did not change between the determinations separated by the interval of 1 hour and the total change in volume in 80 minutes during which pressure was applied 4 times, was only $-.15 \mathrm{ml}$. per $100 \mathrm{ml}$. Hence, if the forearm is first prepared by reducing excess tissue fluid as much as possible it appears that the gradual decrease in reduced forearm volume at normal venous pressure is due not to true absorption of residual extravascular fluid via the capillaries nor to lymphatic drainage, but to mechanical and progressive squeezing out from the plethysmograph either of the plastic tissues of the forearm or of a slight amount of residual fluid.
The adequacy of the precautions taken in preparing subjects was tested further by 3 experiments in which the amount of extravascular fluid was purposely increased by prior venous congestion with a pneumatic cuff inflated to $55 \mathrm{~cm}$. water for an hour. After the usual 90 minutes of preparation, reduced forearm volume was measured every 10 minutes for an hour. The average decreases in forearm volume per application were - .13 to $-.21 \mathrm{ml}$. per $100 \mathrm{ml}$., i.e., slightly greater than in the control experiments but still not significantly different because they were still within the 95 per cent probability range of the control experiments ( +.07 to $-.23 \mathrm{ml}$. per $100 \mathrm{ml}$.).

The 90-minute preparation period was therefore considered sufficiently long to allow for removal from the forearm of such excess fluid as might have been present when the subject first reclined. Because the gradual decrease in volume of the forearm during control observations was apparently a mechanical artefact, the average decrease per application of pressure at $34.5^{\circ} \mathrm{C}$. for each subject was used as a correction factor in all quantitative interpretations of the remaining experimental results.

\section{The effects of temperature on reduced forearm volume (or the volume of extravascular fluid) under resting conditions and normal venous pressure}

The temperature of the water in the plethysmograph was constant within the limits given in Table I except for occasional transient excursions of not more than $1^{\circ} \mathrm{C}$. beyond these limits during deter-

TABLE I

\begin{tabular}{|c|c|c|c|}
\hline \multirow{2}{*}{$\begin{array}{l}\text { Number of } \\
\text { observations }\end{array}$} & \multirow{2}{*}{$\begin{array}{c}\text { Plethysmograph } \\
\text { temperature }\end{array}$} & \multicolumn{2}{|c|}{$\begin{array}{l}\text { Skin temperature within } \\
\text { plethysmograph }\end{array}$} \\
\hline & & Minimum & Maximum \\
\hline $\begin{array}{l}20 \\
10 \\
10 \\
20 \\
7\end{array}$ & $\begin{array}{c}{ }^{\circ} C . \\
4-5 \\
14-15 \\
24-25 \\
34-35 \\
44-45\end{array}$ & $\begin{array}{r}7.5 \\
13.5 \\
24.5 \\
33.5 \\
40.0\end{array}$ & $\begin{array}{l}14.5 \dagger \\
21.0 \dagger \\
28.5 \\
35.5 \\
43.5\end{array}$ \\
\hline
\end{tabular}

* Transient deviations $\pm 1.0^{\circ} \mathrm{C}$. beyond indicated range occurred occasionally.

† 80 per cent between $8.5^{\circ}$ and $12.5^{\circ} \mathrm{C}$.

$\ddagger 80$ per cent between $14.0^{\circ}$ and $19.5^{\circ} \mathrm{C}$. 
minations of volume. At plethysmograph temperatures above or below $34.5^{\circ} \mathrm{C}$. the skin within the plethysmograph was rarely at the same temperature as the water because $(a)$ a thin sheet of rubber separated the water from the skin, and $(b)$ skin temperature was affected by blood flow, which was not interrupted except during the brief periods when external pressure was applied. Hence, as shown in Table I, during exposure to water at $4.5^{\circ}$ C. skin temperatures were usually between $8.5^{\circ}$ and $12.5^{\circ} \mathrm{C}$. (This was about as much cooling as could be tolerated without unbearable pain over the $1 \frac{1}{2}$ hours required for a complete observation.) The temperatures of the skin and the plethysmograph were most nearly equal at $34.5^{\circ} \mathrm{C}$., which can be regarded therefore as a close approach to "neutral" temperature.

The extent to which the forearm was exposed to cooling during the 30 minutes prior to beginning observations varied somewhat depending upon the ease or difficulty of the preliminary adjustments. Room temperatures ranged from $20^{\circ}$ to $29.5^{\circ} \mathrm{C}$. and, with one exception, changed not more than $2.5^{\circ} \mathrm{C}$. during any experiment.

Figure 1 illustrates for one subject the changes in reduced forearm volume when measured at 10minute intervals during continuous exposure of the uncongested arm to 5 temperatures ranging from $4.5^{\circ}$ to $44.5^{\circ} \mathrm{C}$. for periods of an hour or longer. At $4.5^{\circ} \mathrm{C}$., the volume of the forearm increased rapidly at first and then more slowly; a similar but less marked increase in volume occurred at $14.5^{\circ} \mathrm{C}$. It has been mentioned that the apparent decrease at $34.5^{\circ} \mathrm{C}$. is an artefact so that, in absolute terms, volume increased slightly even at $24.5^{\circ} \mathrm{C}$.

Table II summarizes the results obtained in 4 subjects; observed and, for quantitative comparison, also the corrected figures are given. The latter were obtained by adding to each observed reduced forearm volume the total mechanical decrease in volume expected to result from 6 applications of pressure at $34.5^{\circ} \mathrm{C}$. ( 6 times the average decrease per application of external pressure at 10 minute intervals as determined for the same subject in the control experiments)..$^{4}$ The average increase in volume of extravascular fluid at $14.5^{\circ}$ C. was almost double and at $4.5^{\circ} \mathrm{C}$. almost triple that at $24.5^{\circ} \mathrm{C}$. Only small and inconsistent changes occurred at $44.5^{\circ} \mathrm{C}$. It seems clear, however, that the regular and progressive change in volume between $4.5^{\circ} \mathrm{C}$. and $34.5^{\circ} \mathrm{C}$. is arrested or possibly reversed at some temperature between $34.5^{\circ}$ and $44.5^{\circ} \mathrm{C}$. The changes resulting from cooling were largest in E. B. and least in C. W.

4 To test the assumption that the pressure artefact was the same at low temperatures as at $34.5^{\circ} \mathrm{C}$., 2 experiments were done at $4.5^{\circ} \mathrm{C}$. in which 2 pairs of determinations 10 minutes apart were separated by an interval of 60 minutes. In each case the total increase in reduced forearm volume during 60 minutes of exposure to cold without applications of external pressure was considerably greater than that observed during exposure to cold for the same time when readings were made in routine fashion every 10 minutes. The validity of the assumption was also demonstrated quantitatively because the difference in volume at the end of 60 minutes of cooling with and without readings at 10 -minute intervals was approximately equal to that expected from 6 applications of external pressure at $34.5^{\circ} \mathrm{C}$.

TABLE II

Total change in reduced forearm volume (observed and corrected) during 60 minutes at temperatures from $4^{\circ} \mathrm{C}$. to $45^{\circ} \mathrm{C}$.

\begin{tabular}{|c|c|c|c|c|c|c|c|c|c|c|}
\hline \multirow{3}{*}{ Subject } & \multicolumn{10}{|c|}{ Change in volume, $\mathrm{ml}$. per $100 \mathrm{ml}$. of forearm } \\
\hline & \multicolumn{2}{|c|}{4 to $5^{\circ} \mathrm{C}$. } & \multicolumn{2}{|c|}{14 to $15^{\circ} \mathrm{C}$. } & \multicolumn{2}{|c|}{24 to $25^{\circ} \mathrm{C}$. } & \multicolumn{2}{|c|}{34 to $35^{\circ} \mathrm{C}$. } & \multicolumn{2}{|c|}{44 to $45^{\circ} \mathrm{C}$. } \\
\hline & Observed & Corrected & Observed & Corrected & Observed & Corrected & Observed & Corrected & Observed & Corrected \\
\hline $\begin{array}{l}\text { J. S. } \\
\text { C. W. } \\
\text { E. W. } \\
\text { E. B. }\end{array}$ & $\begin{array}{l}+.56^{*} \\
+.21^{*} \\
+.30^{*} \\
+1.04^{*}\end{array}$ & $\begin{array}{r}+1.02 \\
+\quad .67 \\
+.67 \\
+1.79\end{array}$ & $\begin{array}{l}+.26 \\
-.05 \\
+.37 \\
+.27\end{array}$ & $\begin{array}{r}+.72 \\
+.41 \\
+.74 \\
+1.02\end{array}$ & $\begin{array}{l}+.01 \\
-.14 \\
+.06 \\
-.40\end{array}$ & $\begin{array}{l}+.47 \\
+.32 \\
+.43 \\
+.35\end{array}$ & $\begin{array}{l}-.46 \dagger \\
-.46 t \\
-.37 t \\
-.75 \dagger\end{array}$ & $\begin{array}{l}0 \\
0 \\
0 \\
0\end{array}$ & $\begin{array}{l}-.64 \\
-.23 \\
-.46 \\
-.30\end{array}$ & $\begin{array}{l}-.18 \\
+.23 \\
+.09 \\
+.45\end{array}$ \\
\hline $\begin{array}{c}\text { Average } \\
\text { (corrected) }\end{array}$ & & +1.04 & & +.72 & & +.39 & & 0 & & +.10 \\
\hline
\end{tabular}

* Average of 2 experiments.

t Standard of reference and value used as correction figure. Six times the average change in reduced forearm volume per determination when an external pressure of $200 \mathrm{~mm}$. $\mathrm{Hg}$ was applied for 2 minutes out of every 10 minutes. 


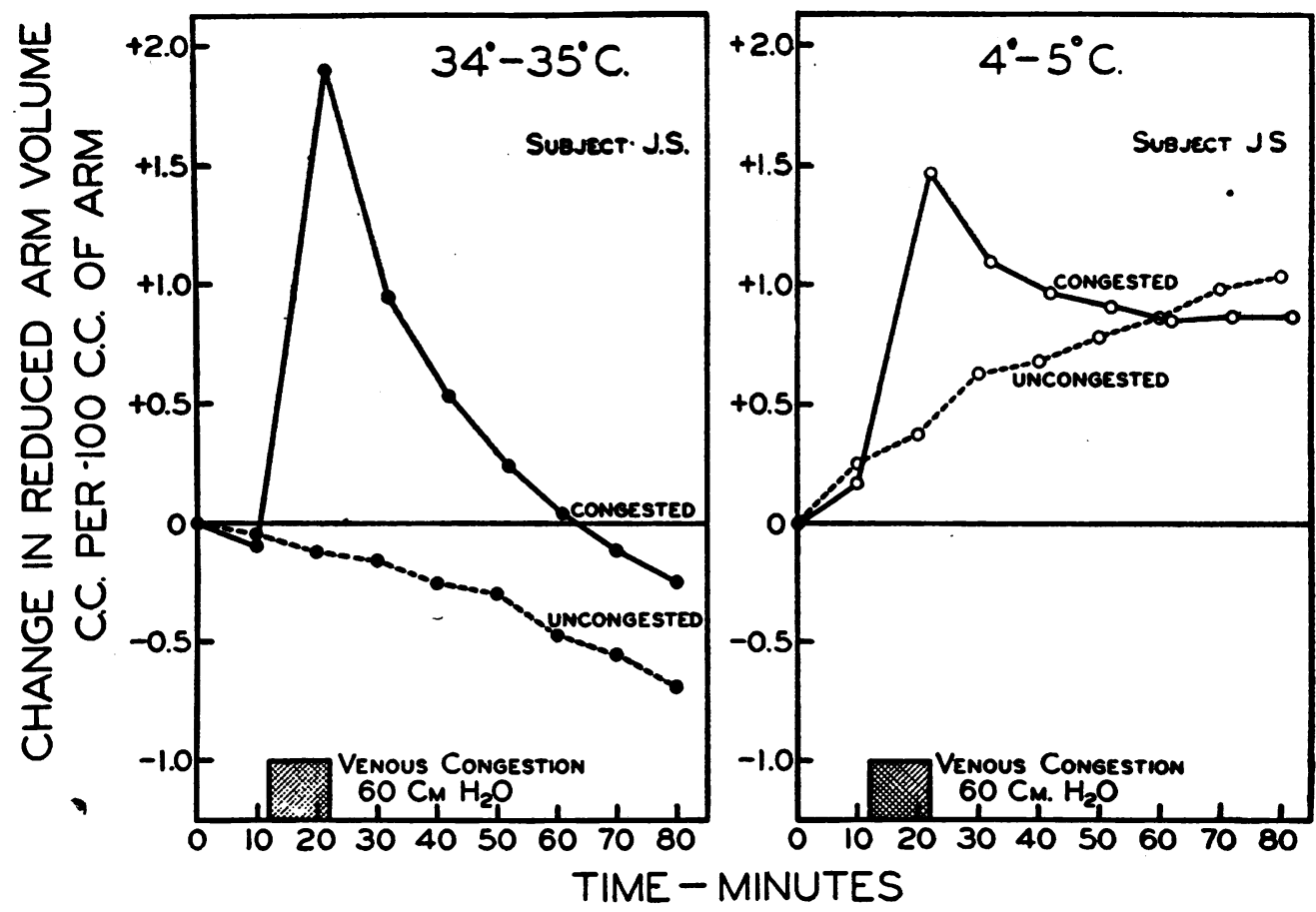

Fig. 2. Changes in Reduced Forearm Volume, in ml. per 100 ml. of Forearm during and after a 10-Minute Period of Congestion at 60 cM. Water Venous Pressure. PlethysMOGRAPH TEMPERATURES $34-35^{\circ}$ AND 4-5 $\mathrm{C}$.

Changes in reduced forearm volume under resting conditions at the same temperatures (see Figure 1) are indicated by dotted lines. Subject J. S.

and E. W.; this relation was fairly consistent throughout the whole series suggesting a real difference between individual subjects.

\section{The effect of temperature on the relation be- tween venous pressure and filtration of fluid}

Landis and Gibbon (7) observed that during congestion at a given venous pressure, $e . g .60 \mathrm{~cm}$. water, for 10 minutes, the volume of fluid which was filtered was greatest at $44^{\circ}$ to $45^{\circ} \mathrm{C}$. and least at $14^{\circ}$ to $15^{\circ} \mathrm{C}$., but they did not test the effect of still lower temperatures. Hence these observations were extended by experiments similar to those shown in Figure 2.

After the usual preparation (totaling $90 \mathrm{~min}$ utes) 2 determinations of reduced forearm volume were made, 10 minutes apart. As external pressure was released after making the second reading, venous pressure was raised abruptly to 20,40 , or $60 \mathrm{~cm}$. water by inflating the pneumatic cuff around the upper arm. Venous congestion was continued for 10 minutes; the cuff was then deflated and reduced forearm volume was measured immediately. Determinations of reduced forearm volume were then repeated at intervals of 10 minutes for totals of 40 to 60 minutes in order to measure the rate at which the recently filtered fluid was reabsorbed or conducted away by the lymphatics.

At $34.5^{\circ}$ C. (solid line, Figure 2, left) the observed increase in reduced forearm volume resulting from 10 minutes of congestion at a venous pressure of $60 \mathrm{~cm}$. water was almost $2.0 \mathrm{ml}$. per $100 \mathrm{ml}$. of forearm. After release of the congesting cuff, the volume of excess tissue fluid which had accumulated as a result of congestion decreased rapidly. For comparison, the changes in reduced forearm volume which took place in the same subject at $34.5^{\circ} \mathrm{C}$. when no congestion was applied are also shown (dotted line, Figure 2, left). At $4.5^{\circ} \mathrm{C}$., the effects of a similar period of congestion differed as follows: (a) reduced forearm volume began to increase even before venous pressure was elevated, $(b)$ the total volume of fluid filtered dur- 
ing congestion was less than at $34.5^{\circ} \mathrm{C}$. rather than more as might have been expected if the only effect of cold were an increase in capillary permeability, (c) the rate of removal of excess fluid after release of the congesting cuff was slower, and (d) reabsorption stopped when the volume of excess tissue fluid was approximately equal to that present after exposing the arm to a temperature of $4.5^{\circ} \mathrm{C}$. for the same time without congestion (dotted line, Figure 2, right).

The results pertaining to filtration in a series of such experiments are summarized in Table III, in which all figures have been corrected to exclude the pressure artefact. In agreement with Landis and Gibbon (7), the volume of fluid filtered was always greater the higher the venous pressure at any given temperature. When venous pressure was $60 \mathrm{~cm}$. water the average rate of filtration was greatest at $34.5^{\circ} \mathrm{C}$., least at $14.5^{\circ} \mathrm{C}$, and then rose again to an intermediate value at $4.5^{\circ} \mathrm{C}$. At a venous pressure of $40 \mathrm{~cm}$. water, average filtration at $4.5^{\circ} \mathrm{C}$. was clearly less than that at $34.5^{\circ} \mathrm{C}$., but the difference was not striking. At a venous pressure of
TABLE III

Effect of temperature of the plethysmograph on rate of filtration of fluid into the tissues of the forearm during 10-minute periods of venous congestion

\begin{tabular}{|c|c|c|c|c|c|c|}
\hline \multirow{2}{*}{$\begin{array}{c}\text { Con- } \\
\text { gesting } \\
\text { pres- } \\
\text { sure }\end{array}$} & \multirow{2}{*}{ Subject } & \multicolumn{5}{|c|}{ Rate of filtration of fluid* } \\
\hline & & $\begin{array}{l}4 \text { to } \\
5^{\circ} \mathrm{C} .\end{array}$ & $\begin{array}{l}14 \text { to } \\
15^{\circ} \mathrm{C} .\end{array}$ & 24 to & $\begin{array}{l}34 \text { to } \\
35^{\circ} \mathrm{C} .\end{array}$ & $\begin{array}{l}44 \text { to } \\
45^{\circ} \mathrm{C} .\end{array}$ \\
\hline \multirow[t]{3}{*}{${ }_{\mathrm{H}_{2} \mathrm{O}}^{\mathrm{Cm}}$} & & $\begin{array}{l}\text { ml. per } \\
100 \text { ml. } \\
\text { per min. }\end{array}$ & $\begin{array}{l}\text { ml. per } \\
100 \text { mel. } \\
\text { per min. }\end{array}$ & $\begin{array}{l}\text { ml. per } \\
100 \text { ml. } \\
\text { per min. }\end{array}$ & $\begin{array}{l}\text { ml. per } \\
100 \text { ml. } \\
\text { per min. }\end{array}$ & $\begin{array}{l}\text { ml. per } \\
100 \text { ml. } \\
\text { per min. }\end{array}$ \\
\hline & $\begin{array}{l}\text { J. S. } \\
\text { C. W. } \\
\text { E. W. } \\
\text { E. B. }\end{array}$ & $\begin{array}{l}.063 \\
.036 \\
.039 \\
.063\end{array}$ & .053 & .074 & $\begin{array}{l}.050 \\
.021 \\
.041 \\
.064\end{array}$ & .058 \\
\hline & Average & .050 & & & .044 & \\
\hline \multirow[t]{2}{*}{40} & $\begin{array}{l}\text { J.S. } \\
\text { C. W. } \\
\text { E. W. } \\
\text { E. B. }\end{array}$ & $\begin{array}{l}.099 \\
.065 \\
.096 \\
.102\end{array}$ & .107 & .106 & $\begin{array}{l}.121 \\
.067 \\
.111 \\
.137\end{array}$ & .118 \\
\hline & Average & .091 & $\cdot$ & & .109 & \\
\hline \multirow[t]{2}{*}{60} & $\begin{array}{l}\text { J. S. } \\
\text { C. W. } \\
\text { E. W. } \\
\text { E. B. }\end{array}$ & $\begin{array}{l}.138 \\
.093 \\
.173 \\
.147\end{array}$ & $\begin{array}{l}.152 \\
.096 \\
.151 \\
.108\end{array}$ & $\begin{array}{l}.185 \\
.093 \\
.147 \\
.184\end{array}$ & $\begin{array}{l}.208 \\
.115 \\
.152 \\
.158\end{array}$ & .226 \\
\hline & Average & .130 & .102 & 152 & .158 & \\
\hline
\end{tabular}

* All values corrected to exclude pressure artefact.

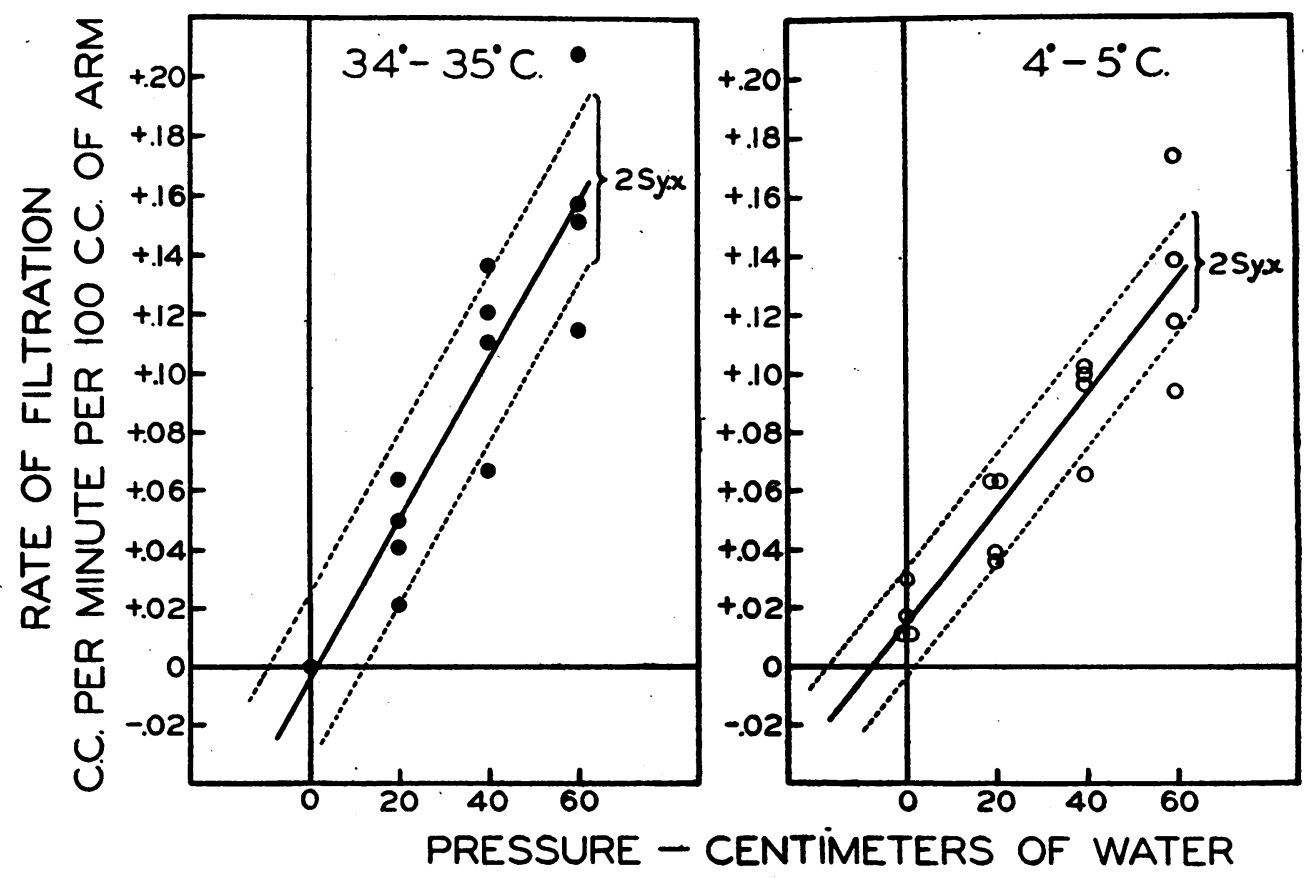

Fig. 3. Rate of Fintration, in ML. Per Minute Per 100 ML. of Forearm during 10Minute Periods of Venous Congestion with Cuff Pressures of 20, 40, and 60 cm. Water. Plethysmograph Temperatures $34-35^{\circ}$ and $4-5^{\circ} \mathrm{C}$.

Changes in reduced forearm volume under resting conditions appear as filtrations at zero, congesting pressure at $45^{\circ} \mathrm{C}$. Four subjects. Results corrected to exclude pressure artefact. 


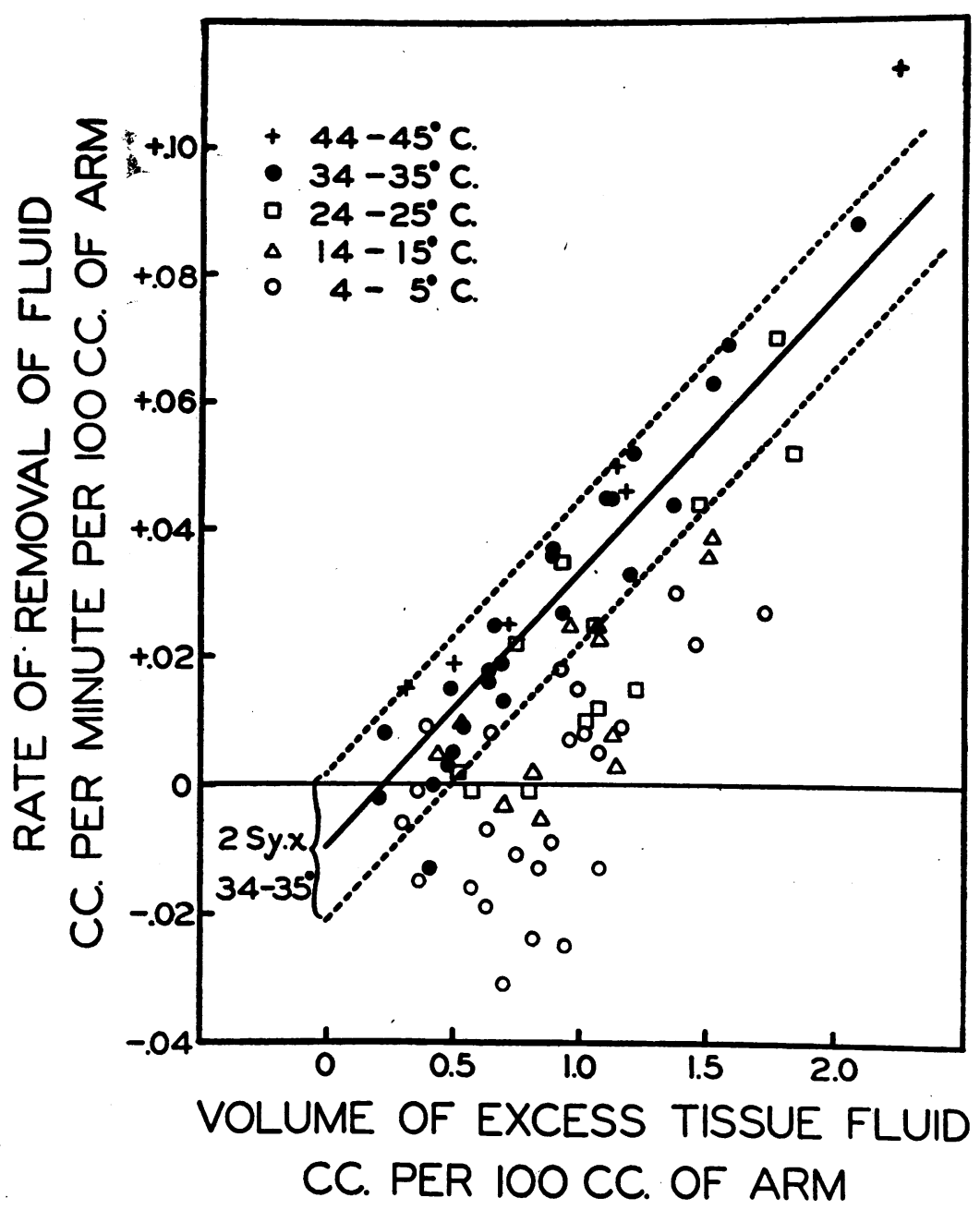

Fig. 4. Relation between the Volume of Excess Tissue Fluid Present, IN ML. PER 100 ML. of Forearm, and the Rate of Reabsorption of Fluid, in ML. Per Minute per $100 \mathrm{ML}$. Of Forearm. Plethysmograph Temperatures $4-5^{\circ}, 14-15^{\circ}, 24-25^{\circ}, 34-35^{\circ}$, AND $44-45^{\circ} \mathrm{C}$.

The volume of excess tissue fluid was obtained from the first 2 observations of reduced forearm volume after 10 minute periods of congestion at venous pressures of 20,40 , and $60 \mathrm{~cm}$. water. Four subjects. Results corrected to exclude pressure artefact.

$20 \mathrm{~cm}$. water the filtration rates were approximately the same at $4.5^{\circ}$ and $34.5^{\circ} \mathrm{C}$. because $(a)$ at this relatively low venous pressure the effects of venous congestion were complicated by the swelling described above for the uncongested arm (Figure 1), and (b) the error for any single measurement was relatively great when small volumes of filtrate were involved.

The linear relation between rate of filtration and grade of venous congestion is shown for $34.5^{\circ} \mathrm{C}$. and for $4.5^{\circ} \mathrm{C}$. in Figure 3. Reasons have been given above for believing that after prolonged preparation of the forearm and at a temperature of $34.5^{\circ} \mathrm{C}$. the corrected, reduced forearm volume is practically constant. Hence, all 4 points relating to the resting forearm (zero congesting pressure) at $34.5^{\circ} \mathrm{C}$. have been placed at zero filtration (Figure 3 , left). At this temperature filtration began as soon as venous pressure was raised above the resting level and increased linearly with increasing grades of venous congestion. At $4.5^{\circ} \mathrm{C}$., filtration occurred at a rate of about $.02 \mathrm{ml}$. per minute per 
$100 \mathrm{ml}$. of forearm even at zero congesting pressure. At this ternperature filtration also increased with increasing congesting pressure, but less rapidly than at $34.5^{\circ} \mathrm{C}$.

The slopes of these lines permit estimation of the unit rate of filtration, i.e., the rate of filtration resulting from each centimeter rise of venous pressure, at each temperature. At $34.5^{\circ} \mathrm{C}$. the unit rate of filtration was $.0027 \mathrm{ml}$. per minute per $100 \mathrm{ml}$. of forearm per $\mathrm{cm}$. venous pressure (standard deviation .00025 ) ; at $4.5^{\circ} \mathrm{C}$., it was $.0019 \mathrm{ml}$. per minute per $100 \mathrm{ml}$. of forearm per $\mathrm{cm}$. venous pressure (standard deviation .00020). The chances are better than 3 out of 4 that this reduction of 30 per cent in the unit rate of filtration was not due to errors of random sampling ( $\mathrm{k} 1.18$ ).

It is noteworthy that at $4.5^{\circ} \mathrm{C}$. the extension of the mean line crosses the line of zero filtration at a pressure of $-9 \mathrm{~cm}$. water. The shift of the intercept toward the left (with respect to the intercept of the line fitting points obtained at $34.5^{\circ}$ C.) is consistent with the view that cold $\left(4.5^{\circ} \mathrm{C}\right.$.) increased the permeability of the capillary walls to protein and that the swelling of the forearm at normal venous pressure (Figure 1) was due to a reduction of the effective colloid osmotic pressure of the blood amounting to approximately $9 \mathrm{~cm}$. water.

\section{The effect of temperature on the rate at which recently filtered extravascular fluid is reab- sorbed after congestion}

Landis and Gibbon (7) observed that small amounts of excess tissue fluid sometimes were removed from the forearm less rapidly during cooling $\left(14^{\circ}\right.$ to $15^{\circ} \mathrm{C}$.) than at higher temperatures. This effect of cold is far more striking at $4.5^{\circ}$ than at $14.5^{\circ} \mathrm{C}$., as shown in Figure 4 where the rate of removal of fluid is charted against the volume of excess tissue fluid present at the time reabsorption was measured. These values were obtained from measurements of reduced forearm volume 10 minutes and 20 minutes after release of the congesting cuff in experiments similar to those illustrated in Figure 2. At each of the 5 temperatures designated, the rate at which fluid was removed was greater when larger volumes of excess tissue fluid were present because tissue pressure was raised by the accumulated fluid (7). At $34.5^{\circ}$
C., a linear relationship became clear (correlation coefficient +.88$)$; at other temperatures the points were more scattered. However, for any given volume of excess tissue fluid, the rate of reabsorption was clearly least at $4.5^{\circ} \mathrm{C}$. In agreement with earlier results $(7)$ the rates of removal at $14.5^{\circ} \mathrm{C}$. were not always reduced and the difference was less conspicuous. The results at $24.5^{\circ}$ and $44.5^{\circ} \mathrm{C}$. were so nearly within the zone of results obtained at $34.5^{\circ} \mathrm{C}$. that conclusions are not warranted.

The marked effect of cold $\left(4.5^{\circ} \mathrm{C}\right.$.) on reabsorption of tissue fluid and the importance of this factor in "immersion foot" are shown more graphically in Figure 2. At $34.5^{\circ} \mathrm{C}$., reabsorption was almost complete within 60 minutes after the end of the period of congestion; at $4.5^{\circ} \mathrm{C}$. reabsorption was slower and remained incomplete, less than half of the filtered fluid having been absorbed at the end of 60 minutes. At $34.5^{\circ} \mathrm{C}$., in 4 subjects, between .43 and $1.19 \mathrm{ml}$. of fluid were removed per $100 \mathrm{ml}$. of forearm tissue during the first $30 \mathrm{~min}$ utes after a prior congestion at $60 \mathrm{~cm}$. water for 10 minutes. At $4.5^{\circ} \mathrm{C}$. during a similar period only .10 and $.32 \mathrm{ml}$. of fluid were removed in 2 subjects and in 2 others the volume of tissue fluid increased by .05 and $.59 \mathrm{ml}$. per $100 \mathrm{ml}$. of forearm tissue. This disturbance of fluid removal is compatible with a reduction of the effective colloid osmotic pressure of the plasma amounting to approximately $10 \mathrm{~cm}$. water.

\section{DISCUSSION}

Determination of the volume of tissue fluid by means of the pressure plethysmograph was made more accurate by having the subject recline with the forearm supported in a vertical position for 90 minutes before observations were begun. This period of preparation permitted capillary absorption and lymphatic drainage to evacuate any excess tissue fluid that had accumulated during immediately prior activity or dependency so that equilibrium was established between the circulating blood and the volume of tissue fluid. Landis and Gibbon (7) did not use this precaution and concluded that successive applications of external pressure did not per se change limb volume consistently and that the decrease in volume was due to continued absorption. It appears now that they observed this transitory absorption because the 
forearm contained tissue fluid remaining from previous activity or dependency. If excess tissue fluid has been removed by suitable preparation, neither filtration nor absorption occurs at $34.5^{\circ} \mathrm{C}$. when the forearm is placed at heart level in the plethysmograph, and the importance of a small and uniform correction for a pressure artefact becomes clear.

The correction for this artefact differed even in normal subjects, being almost twice as great in 2 female subjects as in 3 male subjects. This may be related to differing proportions of muscle, subcutaneous tissue, and skin in their forearms; but the possibility that small amounts of tissue fluid, or even intracellular fluid, are expressed from the regions near the ends of the plethysmograph cannot be excluded. In any case it is important to eliminate any differences in the volume of tissue fluid which may be present in the forearm prior to each experiment and to determine the pressure artefact for each subject, especially if patients with edema are to be studied.

This small correction was relatively unimportant when large volumes of fluid were filtered (e.g. Figure 2 and Table III) but became very important in measuring fluid movement at normal venous pressure and in locating the lowest venous pressure at which filtration began. Thus, without special preparation of the forearm, Landis and Gibbon found that at $34^{\circ}$ to $35^{\circ} \mathrm{C}$. venous pressure had to be raised by 10 to $17 \mathrm{~cm}$. water before a definite increase in the uncorrected volume of the forearm could be produced. With proper preparation and correction for the pressure artefact the line relating venous pressure and filtration passes very close to zero, which is more nearly in accord with the Starling hypothesis (Figure 3, left).

It seems quite clear that cold can produce significant filtration of fluid at resting venous pressure (Figures 1,2, and 3). This is consistent with direct or indirect injury of the capillary wall, increased capillary permeability to protein, and lowering of the effective colloid osmotic pressure of the plasma. The changes actually observed during cooling of the plethysmograph to a given temperature corresponded to smaller changes of tissue temperature because $(a)$ the temperature of the skin was always somewhat higher than that of the water in the plethysmograph (Table I), and (b) deep tissue temperature was even higher than skin temperature (9). Yet slight changes were observed when the plethysmograph was cooled to only $24.5^{\circ} \mathrm{C}$. and when skin temperature was only 5 degrees below the levels usually found when exposed to comfortable environmental air. The effects became progressively more severe as temperature was reduced further. It was not possible to find any critical temperature at which a great increase in filtration appeared abruptly. Table II suggests that at some plethysmograph temperature between $34.5^{\circ}$ and $44.5^{\circ} \mathrm{C}$. (skin temperature between $34.5^{\circ}$ and $42^{\circ} \mathrm{C}$.), the volume of the forearm remained most nearly constant. Above and below that temperature the volume of tissue fluid increased, on the average, even while venous pressure was normal.

The possibility must be considered that the increase in extravascular volume of the uncongested forearm during exposure to cold was due to swelling of cells and not to accumulation of intercellular fluid. This was probably not the case for several reasons. In the first place such increase occurred at rates characteristic of fluid movement through the capillary wall which has a permeability to fluid between 100 and 3000 times greater than that of a typical cell membrane (10). At $4.5^{\circ} \mathrm{C}$., fluid accumulated on the average at a rate of .017 $\mathrm{ml}$. per $100 \mathrm{ml}$. of forearm tissue per minute. Continued accumulation at this rate would produce definite pitting edema in about 10 hours, though developing tissue pressure would decrease the rate of filtration and thus make this period considerably longer. Second, fluid known to be filtered during venous congestion was not reabsorbed fully so that at the end of 80 minutes at $4.5^{\circ} \mathrm{C}$. the extravascular volume after congestion and partial recovery tended to equal that of the uncongested arm after the same period of exposure (Figure 2, right). Third, Lewis (5) was able to obtain several samples of edema fluid containing approximately 3 per cent protein by inserting needles into the subcutaneous tissues of the cooled hand.

Other things being constant, it would be expected that capillary injury would lead not only to filtration of fluid at normal venous pressure, but also to conspicuous increase of filtration rates observed during venous congestion. While the former was observed (Figure 1, Table II), the latter was not (Figure 3). 
This may have been due, in part, to the necessity of exposing the forearm to some cooling during the period of 30 minutes required for adjusting the plethysmograph. Any fluid filtered at resting venous pressure during this time would raise tissue pressure and thereby impede further filtration. It is also possible that increased viscosity of the filtered fluid may have affected filtration, but the differences were greater than would be expected on this basis alone. Of more importance, however, were the concomitant effects of temperature on blood vessels and blood flow in the cooled forearm.

Even while cold was beginning to increase capillary permeability, it was also producing arteriolar constriction, reducing blood flow (9), reducing the gradient of capillary pressure (11), and probably reducing the area of capillary wall available for continued filtration by stopping blood flow in some vessels entirely. Recent studies (9) have shown that blood flow in the forearm is about $17.6 \mathrm{ml}$. per $100 \mathrm{ml}$. of tissue per minute at $45^{\circ}$, $4.3 \mathrm{ml}$. at $35^{\circ}, 0.7 \mathrm{ml}$. at $25^{\circ}$, and $0.5 \mathrm{ml}$. at 10 to $15^{\circ} \mathrm{C}$. Blood flow in the hand is affected similarly except for an increase below $15^{\circ}$ C. (12), but this reactive hyperemia has been ascribed primarily to the opening of arteriovenous anastomoses in the finger tips (13). Incomplete studies (14) have shown that the collective volume of the blood vessels, i.e., the vascular volume, of the forearm is reduced to $1 / 2$ by cooling from $34^{\circ}$ to $24^{\circ} \mathrm{C}$. and to $1 / 3$ by cooling from $34^{\circ}$ to $14^{\circ} \mathrm{C}$. Unfortunately, exact figures are not available for lower temperatures but there is little reason to expect an increase in either blood flow or vascular volume in the forearm at skin temperatures below $10^{\circ}$ to $15^{\circ} \mathrm{C}$. because there are few arteriovenous anastomoses in this region.

It should be noted that such a decrease in blood flow would be expected to reduce the rate at which a diffusible dye such as fluorescein would enter the cooled skin. The results of Lange (6) can therefore be explained on the basis of diminished transport of dye to the cooled tissues and do not indicate that capillary permeability is decreased by cold. In similar fashion the decreased unit rate of filtration observed during exposure to cold was probably a secondary effect of vasoconstriction and hence not evidence against an increase of capillary permeability to protein.
The degree to which permeability to protein was increased by cold can be estimated in terms of the amount by which the effective colloid osmotic pressure of the plasma was reduced, as shown by the observed filtrations and absorptions. During the most extreme cooling, extravascular fluid accumulated in the uncongested forearm at an average rate of $.017 \mathrm{ml}$. per minute per $100 \mathrm{ml}$. of tissue which, according to Figure 3, left, is equivalent to the effect of increasing venous pressure (or decreasing the effective colloid osmotic pressure) by $7.5 \mathrm{~cm}$. water. Comparison of the intercepts in Figure 3 indicates that effective colloid osmotic pressure was reduced by approximately $9 \mathrm{~cm}$. water at $4.5^{\circ} \mathrm{C}$. The delayed absorption at $4.5^{\circ}$ C. shown in Figure 4 is consistent with a reduction of effective colloid osmotic pressure amounting to approximately $10 \mathrm{~cm}$. water. The effective colloid osmotic pressure of the plasma would be lowered as much as this ( 7 to $10 \mathrm{~cm}$. water) by the passage of a capillary filtrate containing 2 per cent protein (15) rather than the normal 0.3 per cent or less (16).

Efforts to substantiate this conclusion by determining the concentration of plasma protein in capillary filtrate by a modification of the method described by Landis et al (16) were unsuccessful; values obtained varied too widely to be conclusive. It may be recalled, however, that Lewis found approximately 3 per cent protein in edema fluid aspirated from the tissues of the hand after prolonged exposure to cold. Despite possible contamination of these samples by blood plasma from mechanical injury or rupture of capillaries, these figures agree well with those calculated from plethysmographic measurements of filtration and absorption at low temperatures.

In contrast to these effects in man it is noteworthy that Brown and Landis (17) found that the frog's capillaries were affected quite differently by cold as is, in fact, necessary for the survival of a poikilothermic animal, exposed for long periods to very low temperatures. When local temperature was decreased $20^{\circ} \mathrm{C}$. the permeability of the walls of single capillaries in the frog's mesentery decreased 73 per cent and there was a significant increase in the total effective osmotic pressure of the blood. The cause for the latter is not clear although thermosmosis or the development of a transient effective osmotic pressure by 
plasma constituents other than proteins are possible explanations that need further study. If either of these factors plays any part in man, the results are unrecognizable because the injurious effects of cold produce more conspicuous changes in the opposite direction.

In the human being, the effect of cold on the balance between blood and tissue fluid is chiefly the result of interplay between capillary injury and reduction of filtering (and absorbing) area. The first, by permitting the passage of protein, reduces the effective colloid osmotic pressure of the blood and favors the formation of edema even when venous pressure is normal. It also prevents the reabsorption of filtered fluid. The second reduces or delays, but does not prevent, filtration when venous pressure is raised as in a dependent extremity. It also delays conspicuously the reabsorption of such tissue fluid as has been filtered previously. If temperature becomes sufficiently low, the edema-producing effects of injury may exceed the edema-preventing factors related to lessened filtering area and reduced blood flow. In Table III, it is shown that filtration during congestion at $60 \mathrm{~cm}$. water declined from $34.5^{\circ}$ to $14.5^{\circ}$ C. but rose sharply again at $4.5^{\circ} \mathrm{C}$. The appearance of striking edema in "immersion foot" (4) is explicable on this basis because the syndrome appears when the dependent extremities are exposed for brief periods to very low temperatures or for longer periods to temperatures which are only moderately low.

\section{SUM MARY}

1. The pressure plethysmograph was used to measure changes in the extravascular ("reduced") volume of the forearm in 4 normal human subjects, in order to determine the effects of local cooling on $(a)$ the volume of tissue fluid under resting conditions, $(b)$ the rate of filtration of fluid per unit increase of venous pressure and (c) the rate of reabsorption of excess tissue fluid after release of venous congestion.

2. The accuracy of this method for measuring minute changes in the volume of tissue fluid has been improved ( $a$ ) by elevating the forearm for 90 minutes to remove residual tissue fluid before each observation, and $(b)$ by measuring for each subject the small error or artefact introduced each time a volume is read while applying to the forearm an external pressure of $200 \mathrm{~mm}$. $\mathrm{Hg}$.

3. Cold produced filtration of fluid and increased the volume of tissue fluid even in the uncongested forearm. The average rate of filtration at $4.5^{\circ} \mathrm{C}$. was $.017 \mathrm{ml}$. per $100 \mathrm{ml}$. of forearm tissue per minute. Smaller rates of filtration were observed at $14.5^{\circ}$ and $24.5^{\circ} \mathrm{C}$. At $34.5^{\circ}$ and $44.5^{\circ} \mathrm{C}$. reduced forearm volume did not change significantly.

4. The rate of filtration remained directly proportional to the increase in venous pressure even at $4.5^{\circ} \mathrm{C}$., but the unit rate of filtration $(\mathrm{ml}$. fluid per $100 \mathrm{ml}$. of forearm per minute per $\mathrm{cm}$. rise of venous pressure) was 30 per cent less at $4.5^{\circ} \mathrm{C}$. than at $34.5^{\circ} \mathrm{C}$.

5. Cold reduced the rate of reabsorption of previously filtered fluid conspicuously at $4.5^{\circ} \mathrm{C}$. and slightly at $14.5^{\circ} \mathrm{C}$.

6. The results collectively indicate that cold increases the permeability of the human capillary wall to protein. In the forearm exposed to water at $4.5^{\circ} \mathrm{C}$., this reduces the effective colloid osmotic pressure of the blood by 7 to $10 \mathrm{~cm}$. water.

7. The relation between these findings and the pathogenesis of edema in extremities exposed to cold, e.g. "immersion foot," is discussed.

\section{ACKNOWLEDGMENT}

It is a great pleasure to have this opportunity to thank Dr. E. M. Landis for his guidance during the planning and conduction of the experiments and the preparation of this report.

\section{BIBLIOGRAPHY}

1. Davis, L., Scarff, J. E., Rogers, N., and Dickinson, M., High altitude frostbite. Preliminary report. Surg., Gynec. \& Obst., 1943, 77, 561.

2. Lewis, T., and Love, W. S., Vascular reactions of the skin to injury. III. Some effects of freezing, of cooling and of warming. Heart, 1926, 13, 27.

3. Greene, $R$., The immediate vascular changes in true frostbite. J. Path. \& Bact., 1943, 55, 259.

4. Ungley, C. C., Channell, G. D., and Richards, R. L., The immersion foot syndrome. Brit. J. Surg., 1945, 33, 17.

5. Lewis, T., Swelling of the human limbs in response to immersion in cold water. Clin. Sci., 1939, 4, 349.

6. Lange, $K$., The effect of cold on capillary permeability, preliminary report. Bull. New York M. Coll., 1942, 5, 154.

7. Landis, E. M., and Gibbon, J. H., The effects of temperature and of tissue pressure on the movement of fluid through the human capillary wall. J. Clin. Invest., 1933, 12, 105. 
8. Krogh, A., Landis, E. M., and Turner, A. H., The movement of fluid through the human capillary wall in relation to venous pressure and to the colloid osmotic pressure of the blood. J. Clin. Invest., 1932, 11, 63.

9. Barcroft, H., and Edholm, O. G., The effect of temperature on blood flow and deep temperature in the human forearm. J. Physiol., 1943, 102, 5.

10. Landis, E. M., Capillary pressure and capillary permeability. Physiol. Rev., 1934, 14, 404.

11. Landis, E. M., Micro-injection studies of capillary blood pressure in human skin. Heart, 1930, 15, 209.

12. Spealman, C. R., Effect of ambient air temperature and of hand temperature on blood flow in the hand. Am. J. Physiol, 1945, 145, 218.
13. Grant, R. T., and Bland, E. F., Observations on arteriovenous anastomoses in human skin and in the bird's foot with special reference to the reaction to cold. Heart, 1931, 15, 385.

14. McLennan, C. E., and Landis, E. M., Unpublished observations.

15. Wies, C. H., and Peters, J. P., The osmotic pressure of proteins in whole serum. J. Clin. Invest., 1937, $16,93$.

16. Landis, E. M., Jonas, L., Angevine, M., and Erb, W., The passage of fluid and protein through the human capillary wall during venous congestion. J. Clin. Invest., 1932, 11, 717.

17. Brown, E., and Landis, E. M., Effect of local cooling on fluid movement, effective osmotic pressure and capillary permeability in the frog's mesentery. Amer. J. Physiol., 1947, 149, 302. 